\title{
Storytelling, a new approach in empowering mothers in the prevention of childhood accidents
}

\author{
$\underline{\text { Zahra Vahdaninya }}{ }^{1}(\mathbb{D})$, Maryam Nakhaei $^{2}(\mathbb{D})$, Gholamreza Sharifzadeh $^{3}(\bar{D})$, \\ Ahmad Nasiri' ${ }^{2}$,Bibi Fatemeh Baghernejad Hesari ${ }^{3}(\mathrm{D})$
}

${ }^{1}$ Corresponding author; Social determinants of health research center, Birjand University of Medical Sciences, Birjand, Iran. Tel:+985632395461 Fax:+985632445672Ｅ-mail:vahdane@bums.ac.ir

${ }^{2}$ Department of Nursing, Faculty of Nursing and Midwifery, Birjand University of Medical Sciences, Birjand, Iran

${ }^{3}$ Social determinants of health research center, Birjand University of Medical Sciences, Birjand, Iran

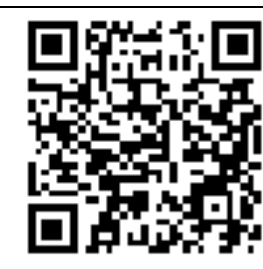

Citation Vahdaninya Z, Nakhaei M, Sharifzadeh G, Nasiri A, Baghernejad Hesari BF. [Storytelling, a new approach in empowering mothers in the prevention of childhood accidents]. J Birjand Univ Med Sci. 2019; 26(2): 176-85. [Persian]

DOI http://doi.org/10.32592/JBirjandUnivMedSci.2019.26.2.109

Received: December 23, 2017

Accepted: May 6, 2018

\begin{abstract}
Background and Aim: Children due to specific physiological and behavioral characteristics, more than others are at risk of accidents and need care by an adult; therefore, the present study aims to investigate the effect of education in two methods, storytelling and self-learning have been done on the ability of mothers to prevent children's accidents.

Materials and Methods: The present research is a randomized field trial study which was performed on 60 mothers with children aged 1 to 59 months. The research tool is a researcher-made questionnaire whose validity and reliability have been proven. Meetings for training the principles of preventing the common accidents in the province in two "storytelling" and "self-learning" methods were held in 24 training sessions. data analysis was performed by Chi-square, Fisher test, Independent t-test, Bonferroni post hoc and repeated ANOVA tests at $\alpha=0.05$

Results: Both training methods significantly enhanced the empowerment score of the mothers compared to before ( $<<0.001)$. Comparing two methods, although there was no significant difference in the mean of power score changes before and the immediately after the intervention, but the average of changes in the score three months later showed a significant difference before and immediately after that and storytelling could have a more effective effect on improving the ability of mothers three months after intervention $(\mathrm{P}=0.02)$ and immediately thereafter $(\mathrm{P}=0.04)$.
\end{abstract}

Conclusion: Education in both ways can lead to mothers' ability; however, due to reduced ability score after three months in the selflearning group, storytelling is more effective in mothers.

Key Words: Storytelling; Self-Learning; Childhood Accidents 


\title{
داستان كويى، روشى نوين براى تواذمندسازى مادران در زمينه بيشكيرى از حوادث كودكان
}

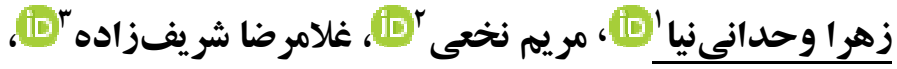

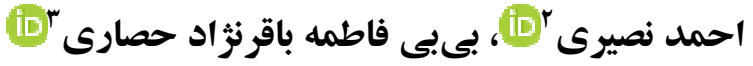

\section{جكيده}

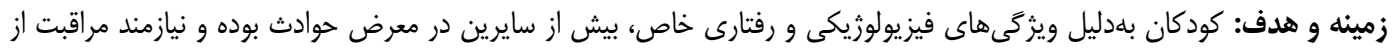

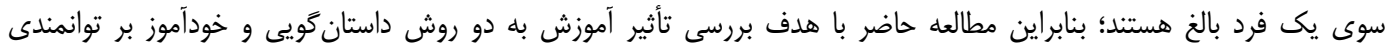

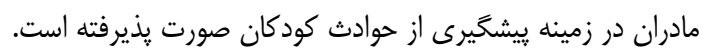

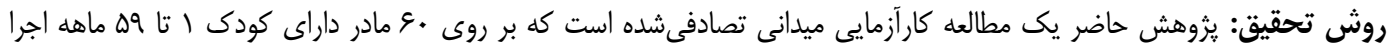

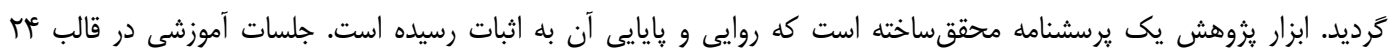

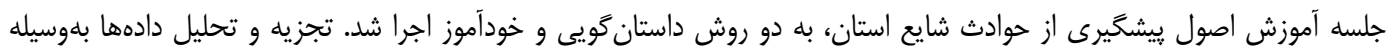

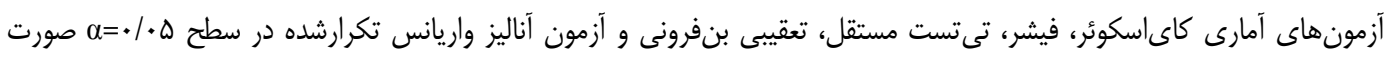

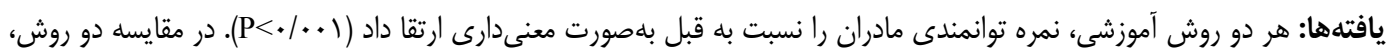

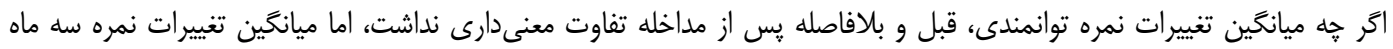

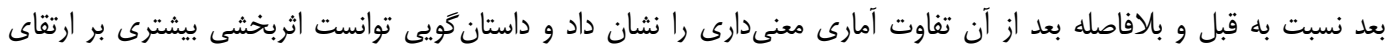

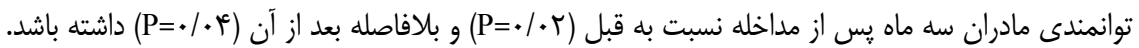

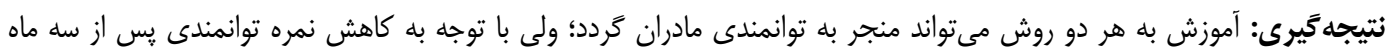

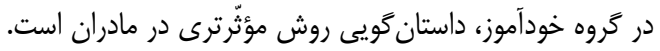

$$
\text { وازههاى كليدى: داستان كَيى؛ خودآموز؛ حوادث كودكان }
$$

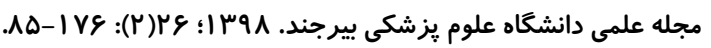
دريافت: •/|• |

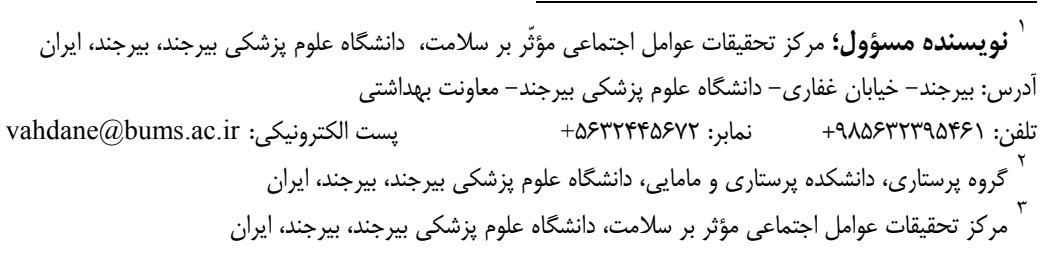


مطالعات خود اهميت نقش مادران در پيشگيرى از حوادث كودكان را مورد تاكيد قرار دادهاند (1- (ج).

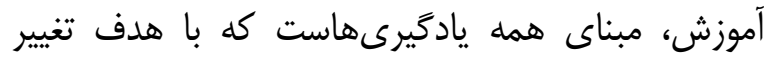
رفتار فرد صورت مى گيرد. آموزش با روشهاى مهذى مختلفى ارائه

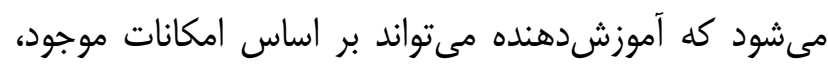

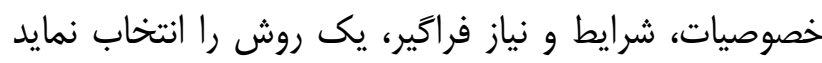

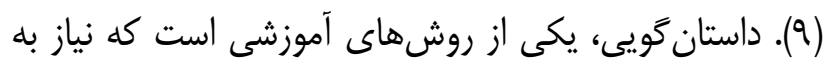

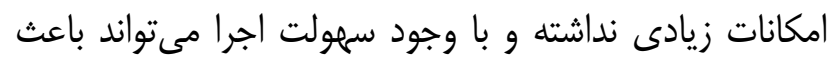

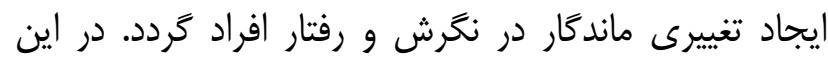
راستا، در مطالعهاى كاهش معنى دار افسردگى كودكان بلهدنبال

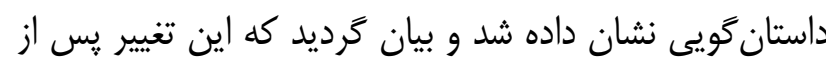

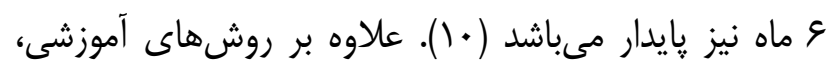

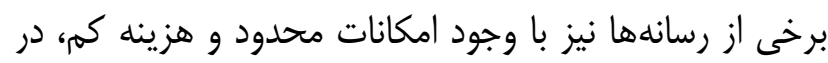

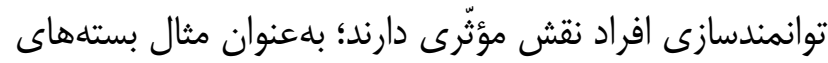

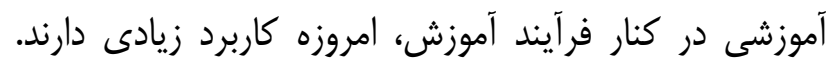

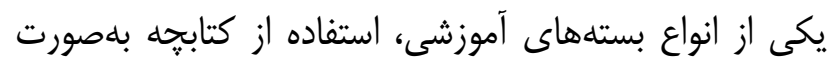
نوشتارى است كه در كشور ما كاربرد زيادى دارد. اين بستهها

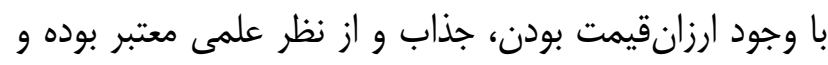
با امكانات كمتر نسبت به برخى از رسانههاى ديخر آماده

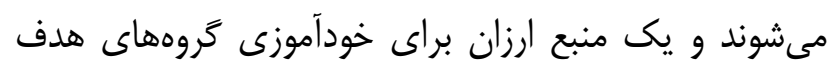

$$
\text { بالشمار مىروند. (9) }
$$

با توجه به آنكه حوادث خانكى براى كودكان از ميزان

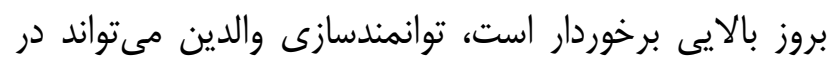

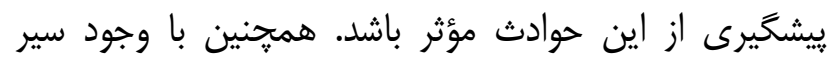

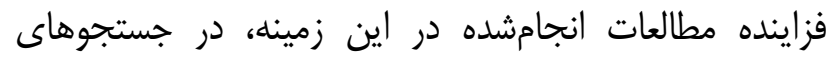

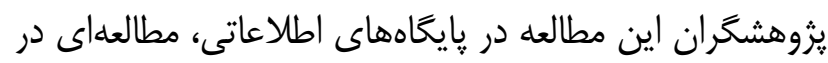

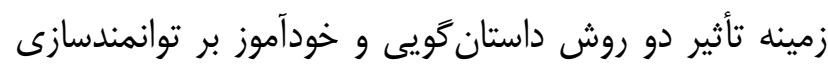

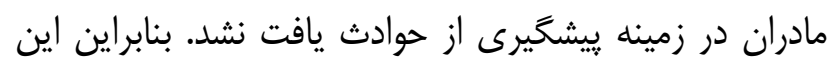

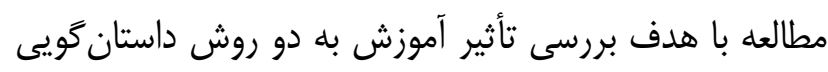

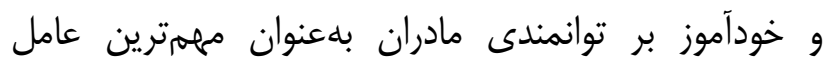

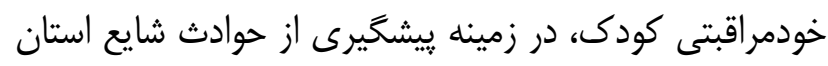

مقلدمه

حوادث همواره در طول تاريخ از عوامل مهم مرگ و

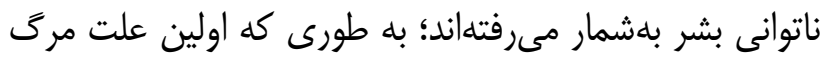

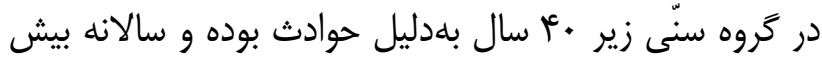

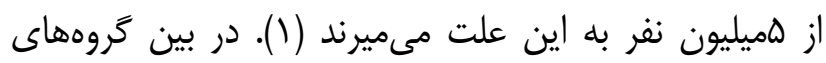

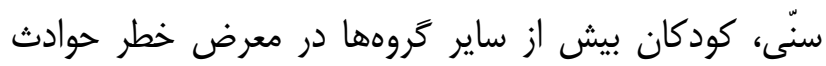

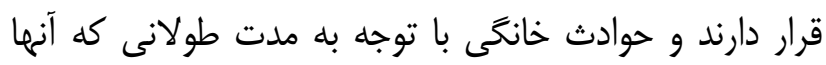

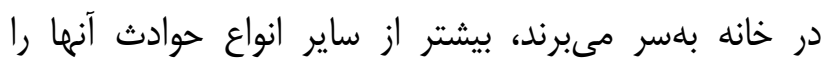

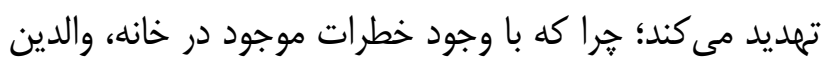
اغلب محيط خانه را محيطى امن براى كودكان مىدانند؛ در

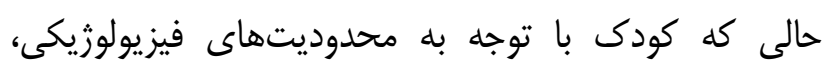
تكاملى و رفتارى خاص خود بيشتر از ساير اعضاى خانواده در

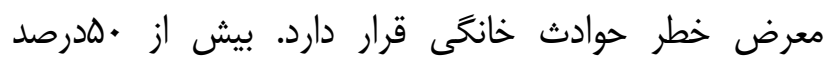

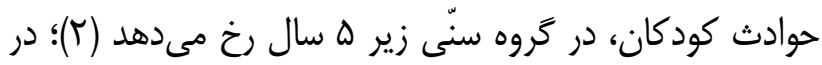

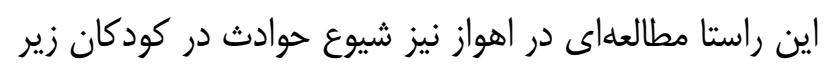
ه سال را •• درصد گزارش كرد (َّ).

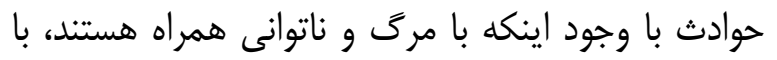

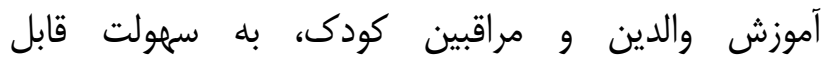
ييشگيرىاند؛ به طورى كه بر اساس گزارش سازمان جهانى

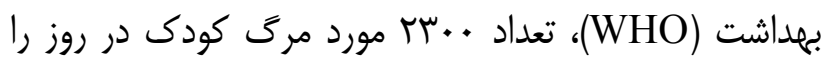

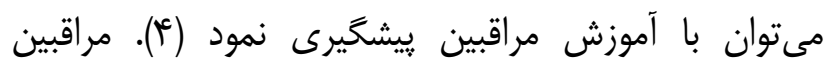

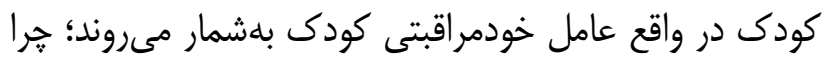
كه خودمراقبتى، رفتارى حاصل از توانمندى فرد و تقاضاى

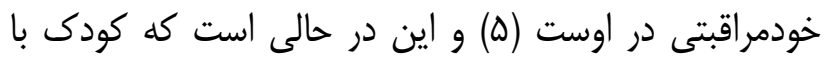

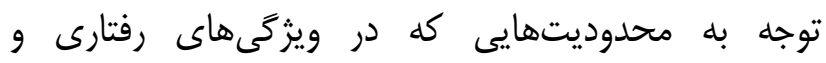

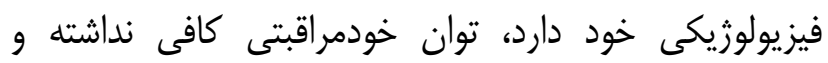
تقاضاى خودمراقبتى نيز در وى شكل نكل نخرفته و ون نيازمند دريافت مراقبت از سمت يك شخص توانمند است. در ميان دئ مراقبين كودى، مادر بيشترين زمان را در كنار كودكش ستش

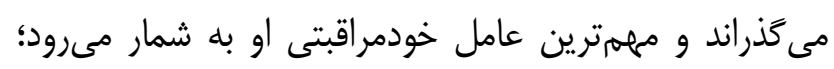

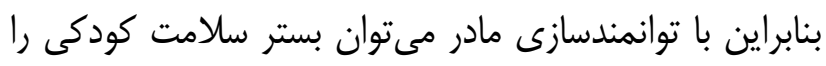

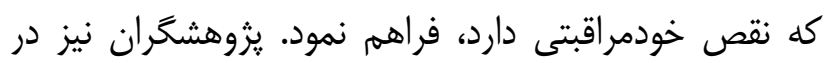


تصادفى از اين ليست انتخاب گَرديد و از طريق تماس تلفنى از

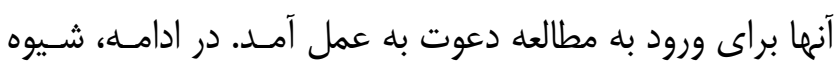

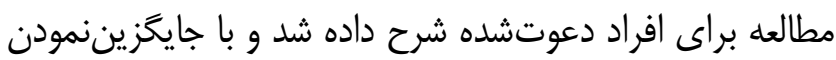

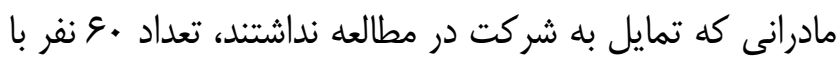

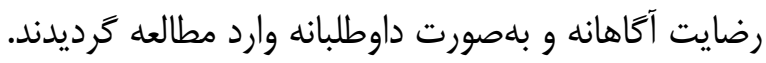
ابزار مورد استفاده در اين مطالعه يك يرسشنامه بهاه

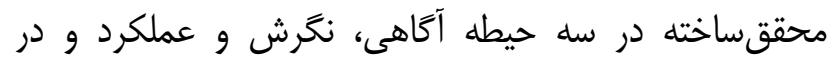

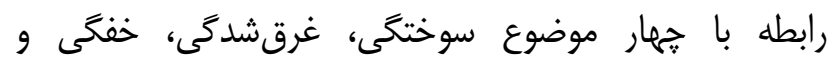

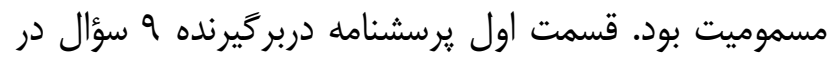

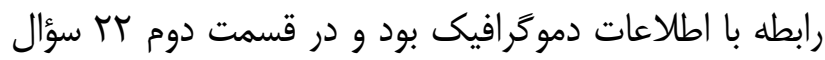

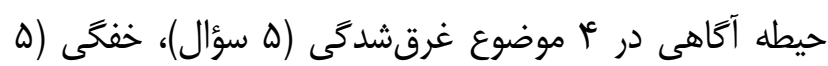

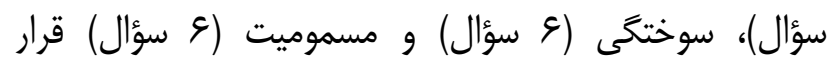

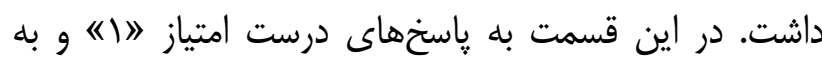

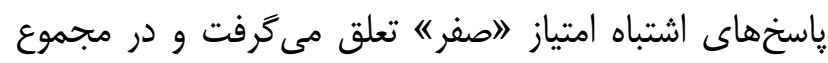

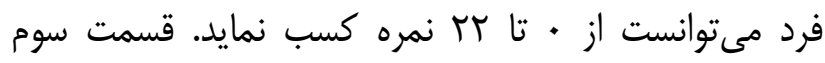

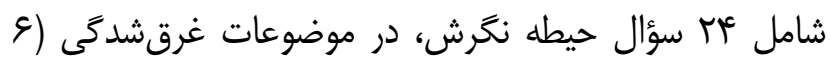

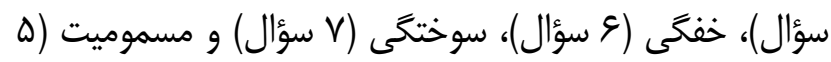

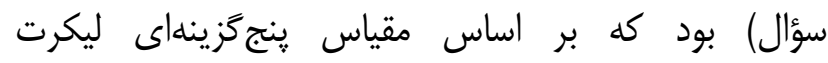

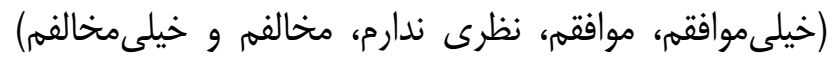

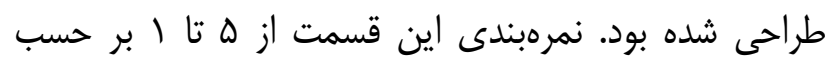

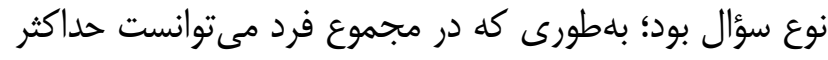

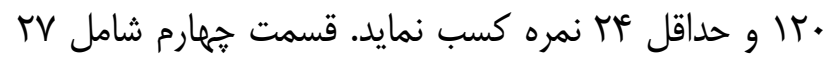
سؤال حيطه عملكرد در موضوعات غرقشدگى (ع سؤال)، خفكى (צ سؤال)، سوختخى (V سؤال) و مسموميت (ه سؤال)

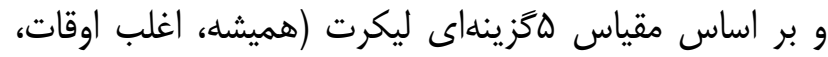

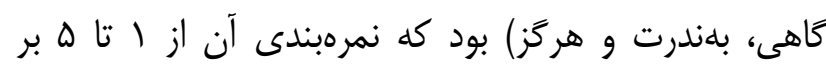

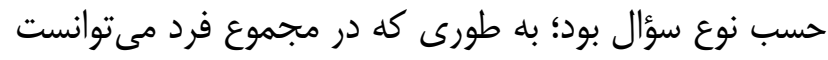

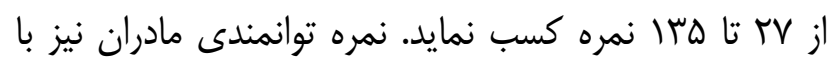

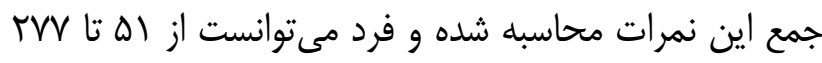

$$
\text { نمره كسب نمايد (جدول () ). }
$$

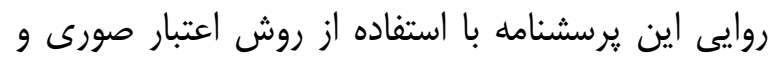

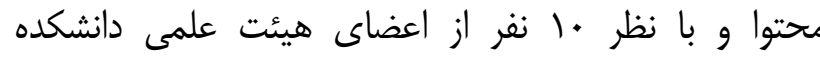

يزوهش حاضر يك مطالعه كارآزمايى ميدانى تصادفىشده

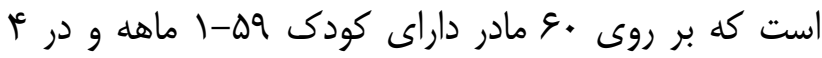
يايعاه خدمات جامع سلامت شهر بيرجند اجرا گرديد. تعداد

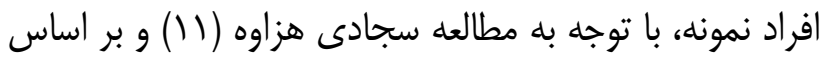
فرمول (I) محاسبه گرديد. بر اساس محاسبات انجامشده،

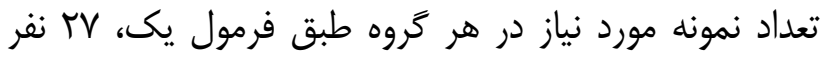
محاسبه شد كه براى افزايش دقت و با توجه به احتمال

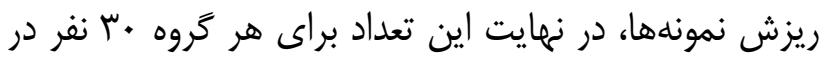
نظر كرفته شد. فرمول (1): - (1) $\frac{\left(z_{1}-\frac{\alpha}{2}+z_{1}-\beta\right)^{2} \times\left(s_{1}^{2}+s_{2}^{2}\right)}{(d)^{2}}=\frac{(1.96+0.84)^{2} \times\left(11.7^{2}+14.8^{2}\right)}{100}=26.62=27$ شرايط ورود به مطالعه شامل: تحت يوشش مراكز تعيينشده بودن، دارابودن حداقل يك كودى در محدوده

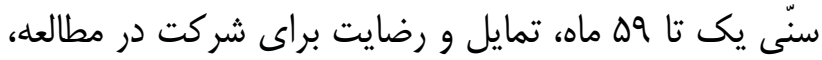

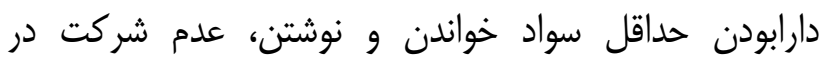

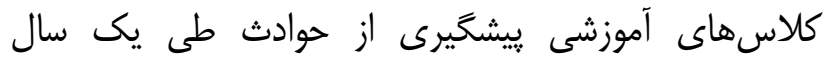

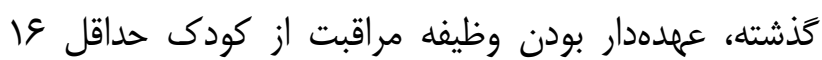
ساعت در روز، مطلقه يا بيوه نبودن، عدم وجود سابقه بسترى

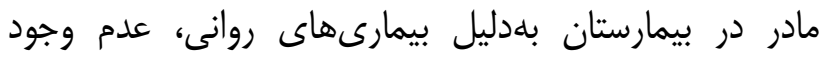

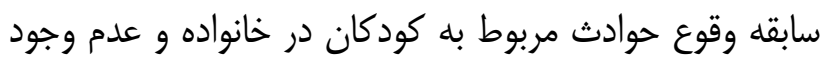

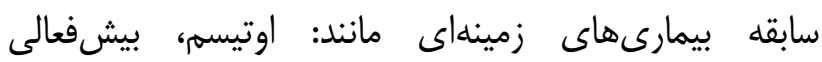
تشخيص داده شده، عقبماندكى ذهنى و اختلالات تكاملى زمانى

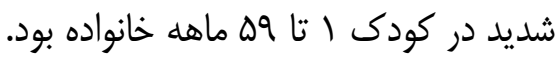

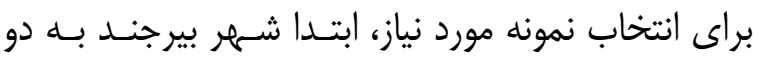

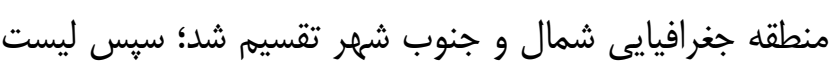

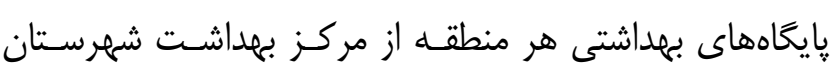

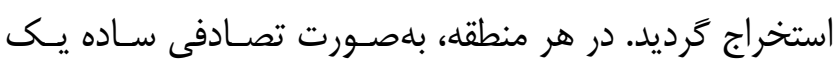

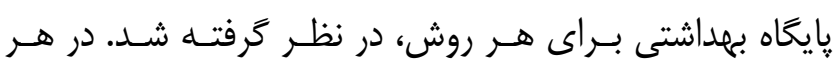

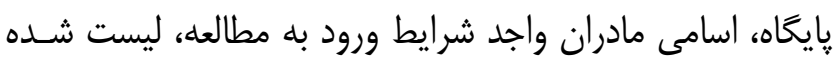

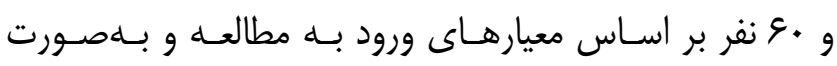




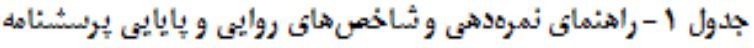

\begin{tabular}{|c|c|c|c|c|}
\hline \multirow{2}{*}{ نمره توانهناثى مادر } & \multicolumn{3}{|c|}{ حيطادها } & \multirow{2}{*}{ 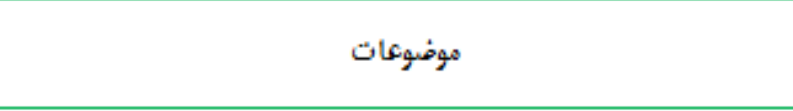 } \\
\hline & عملكرد & 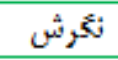 & أكاهيى & \\
\hline $11-9$. & $\Delta-r \Delta$ & $9-r$. & $-\Delta$ & 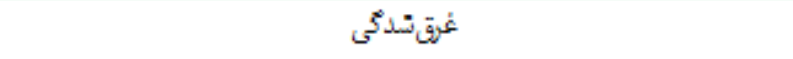 \\
\hline$\pi-\gamma$. & $Y-T \Delta$ & $\varepsilon-r$. & $-\Delta$ & مفكى \\
\hline If-Ye & $\gamma-r_{\Delta}$ & $\gamma-r \Delta$ & -9 & سوختكى \\
\hline$|r-\gamma|$ & AF. & $\Delta-r \Delta$ & -9 & مسmang \\
\hline$\Delta L r r$ & ra-ita & $r=1 \%$. & .4 & 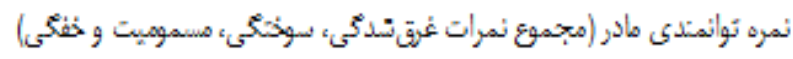 \\
\hline- & $4 / \mathrm{AY}$ & $/ N$ &.$/ \mathrm{W}$ & تيتيجه أزمون ألفاى كرونباخ \\
\hline- & $/ 94$ &.$/ 9 \Delta$ & 1 & $\mathrm{CVI}^{\prime}$ \\
\hline \multirow[t]{2}{*}{-} &.$/ 9 \%$ &.$/ 4$ & .94 & $\mathrm{CVR}^{r}$ \\
\hline & $\Delta / \mathrm{W}$ &.$/ \mathrm{V} \Delta$ & $d N$ & ICC $^{3}$ \\
\hline
\end{tabular}

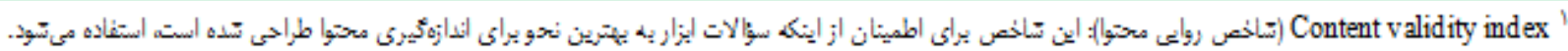
(نontent validity ratio ${ }^{\top}$ Interclass correl ation coefficient ${ }^{\top}$

منابع معتبر علمى، تهيه شد و سناريوهاى مربوط به شايعترين

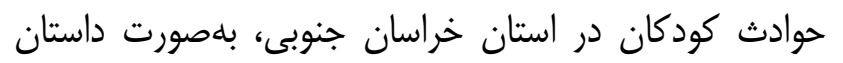

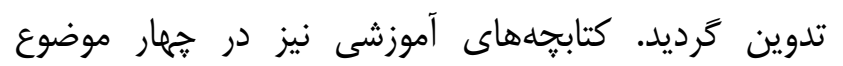

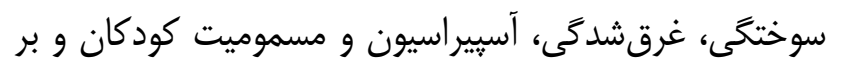

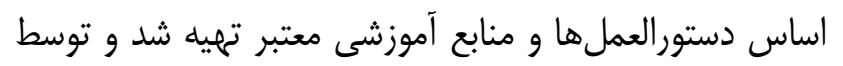

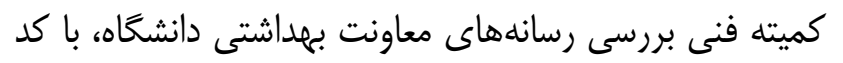

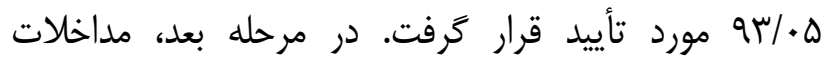

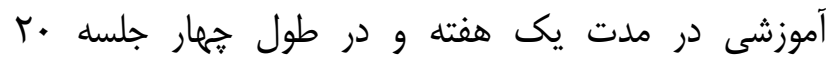

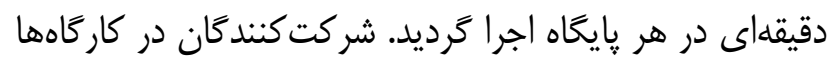

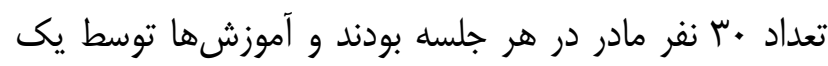

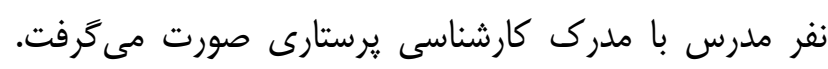

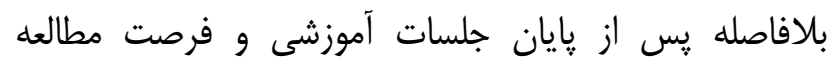

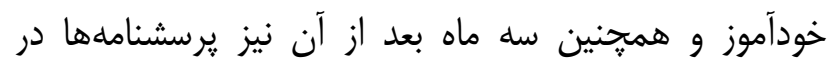

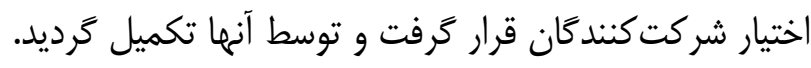

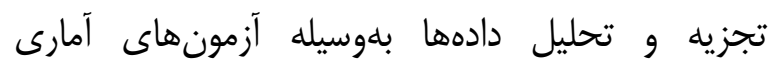
كاى اسكوئر، فيشر، تى تست مستقل، تعقيبى بن فرونى و آزمون

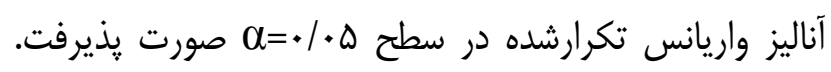

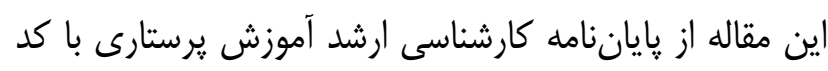

يرستارى و مامايى، دانشكده بهداشت و مركز فوريتهاى

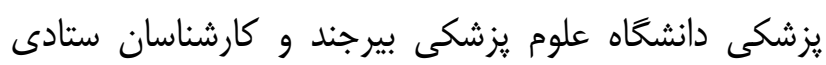

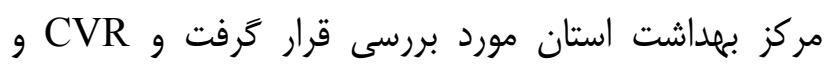
CVI

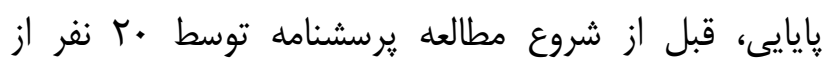
افرادى كه معيارهاى ورود به مطالعه را داشتند اما در مطالعه تئه حاضر وارد نشده بودند، تكميل و همسانى درونى سؤالات از وناز

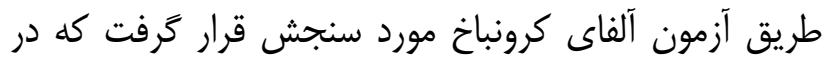
تمام موارد بالاتر از ^/ • تعيين گرديد.

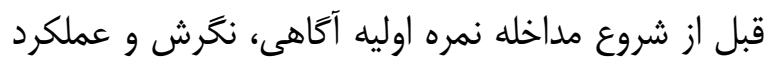

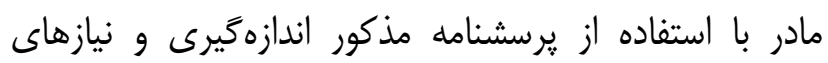
آموزشى مادر بهعنوان عامل خودمراقبتى كودى محاسبه شد ادئ

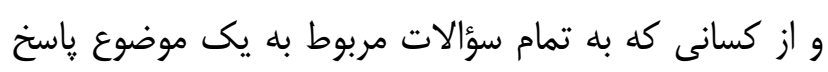

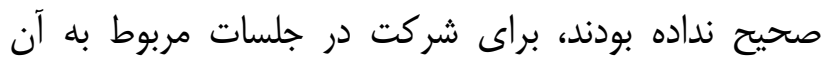

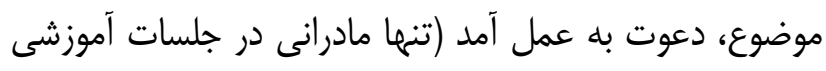

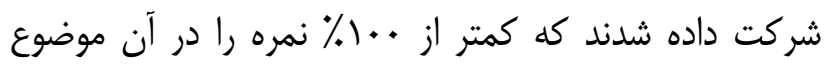

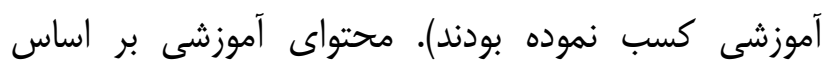

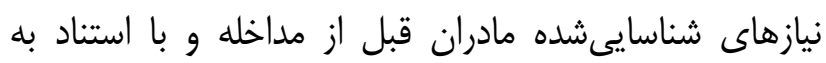


هر جند نمره آكَاهى گروه هدف سه ماه بعد از مداخله كاهش

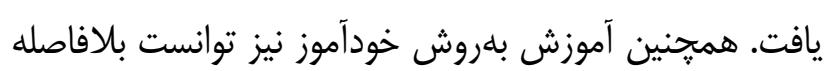

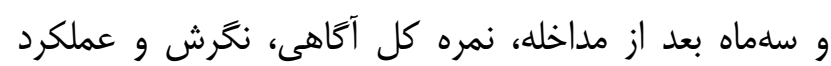

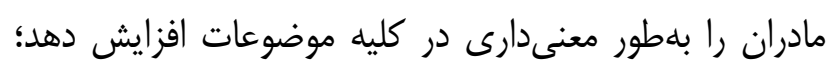

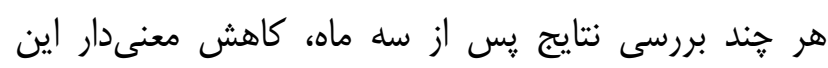

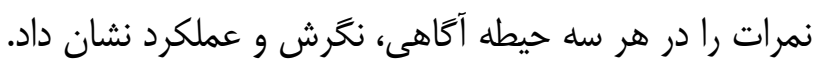

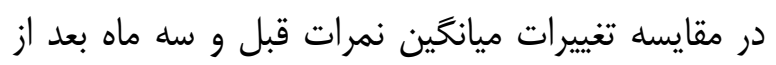

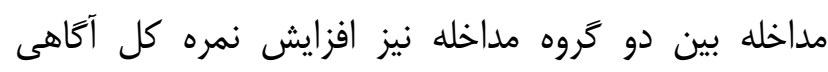

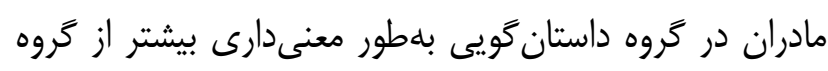

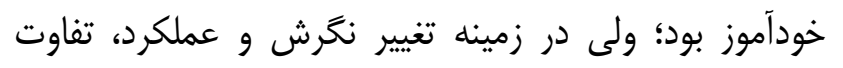

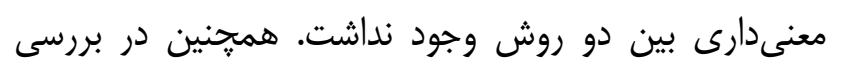

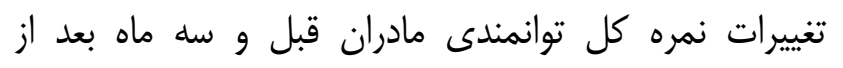

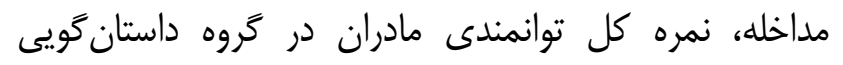

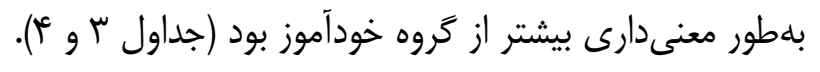

اخلاق Ir.bums.REC.1394.424 استخراج گرديده است.

\section{يافته ها}

ميانگَين سن مادران در دو گَروه خودآموز و داستان گَويى به ترتيب:

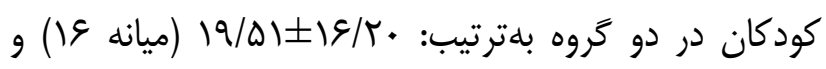

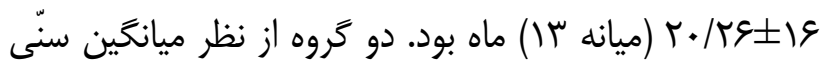

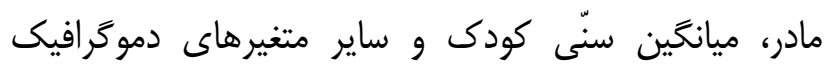

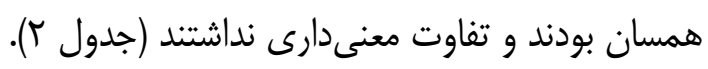

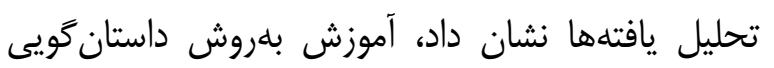

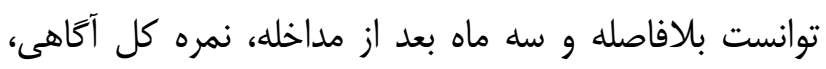

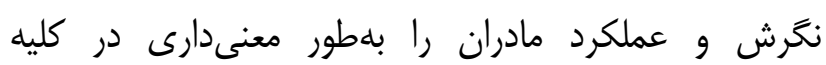

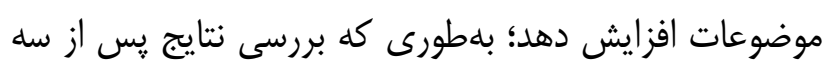

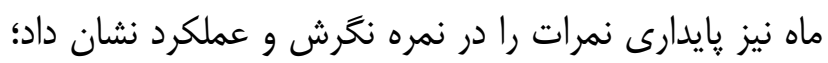

جدول r- مقايسه مشخصات دموتَ, افيك در دو تروه داستان تويى و كتابجهآموز

\begin{tabular}{|c|c|c|c|c|c|}
\hline \multirow{2}{*}{ كآزمون تى تسك معنى مسارى } & \multirow[b]{2}{*}{ نوع آزمون } & \multicolumn{2}{|c|}{ روش } & \multirow{2}{*}{\multicolumn{2}{|c|}{ متغيّر }} \\
\hline & & كتابجه آموزشى & داستان كويى & & \\
\hline \multirow{3}{*}{.$/ 19$} & \multirow{3}{*}{ آزمون كاى اسكوئر } & IV $0^{*} /{ }^{\mu}$ & $10 / \mathrm{mv}$ & & \\
\hline & & 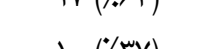 & (r) & 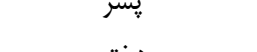 & جس \\
\hline & & $1 .(\% \mathrm{~N})$ & & & (\%) وراوانى \\
\hline \multirow{3}{*}{$\cdot|\Delta|$} & \multirow{3}{*}{ آزمون فيشر } & $r(\% V / F)$ & $F(\% / \% / \Lambda)$ & نهضت و ابتدايى & \\
\hline & & זו $(\% \mathcal{N} N)$ & ז $(\%(\% \mathcal{N} / 1)$ & راهنمايى و متوسطه & مصنيلات مادر \\
\hline & & $\operatorname{Ir}(\% \varphi c / \mathcal{L})$ & $1 \cdot(\% \mathrm{rV})$ & تحصيلات دانشخاهي & (•/) قراواتى \\
\hline \multirow{2}{*}{ ת } & \multirow{2}{*}{ آزمون كاىاسكوئر } & $\operatorname{Tr}(\% \wedge \mathrm{A} / \Delta)$ & $19(\% \cdot / / 4)$ & خانهدار & وضعيت شغل \\
\hline & & $\Delta(\% N / \Delta)$ & $\Lambda(\% \vee q / q)$ & ش اغاغل & ـ (\%) فراوانى \\
\hline.$/ 94$ & آزمون كاى اسكوئر & Ir $(\% \uparrow N / 1)$ & Ir $(\% \mathcal{N} / 1)$ & اولين فرزند & ر (\%) فراواني كودى \\
\hline$\cdot / \Delta \Delta$ & تىىتست مستقل & $r q / r^{c} \vee \Delta / r$ & $r q / \Delta V \pm \cdot / r$ & $\mathrm{M} \pm \mathrm{SD}$ & سن مادر \\
\hline.$/ 14$ & تى تست مستقل & $\begin{array}{c}19 / \Delta| \pm| 1 / T . \\
19=0 \text { ميانه }\end{array}$ & 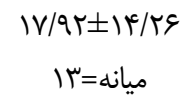 & $\mathrm{M} \pm \mathrm{SD}$ & 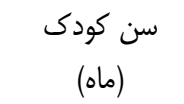 \\
\hline
\end{tabular}


جدول ب- مقايسه ميانكَين نمره آََاهى، نكَرش، عملكرد و توانمندى مادران قبل، بعد و سه ماه بعد از مداخله، در كَروه خودآموز و داستانَّويى

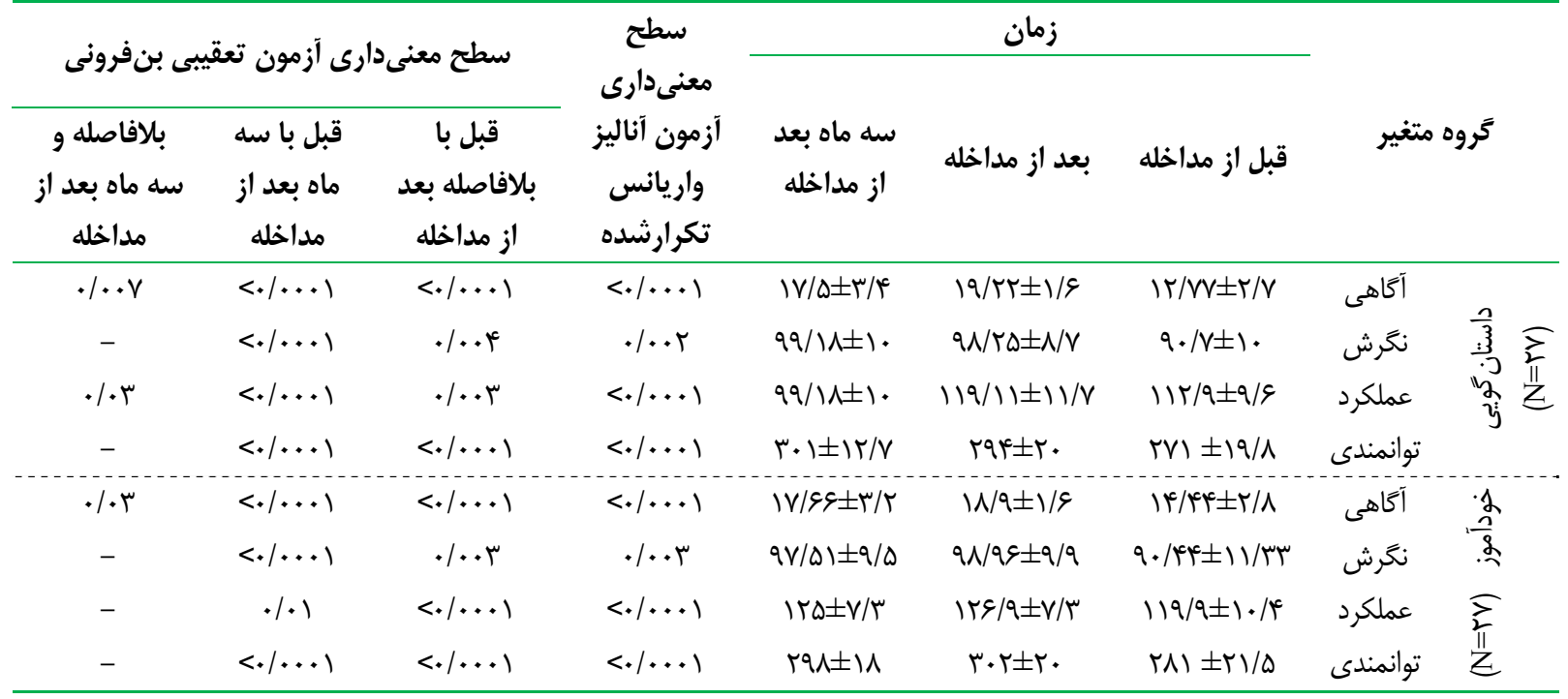

جدول fأ- مقايسه ميانكَين تغييرات نمره آكاهى، نتَرش عملكرد و توانمندى مادران قبل ، بعد و سه ماه بعد از مداخله، در تَروه خودآموز و

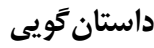

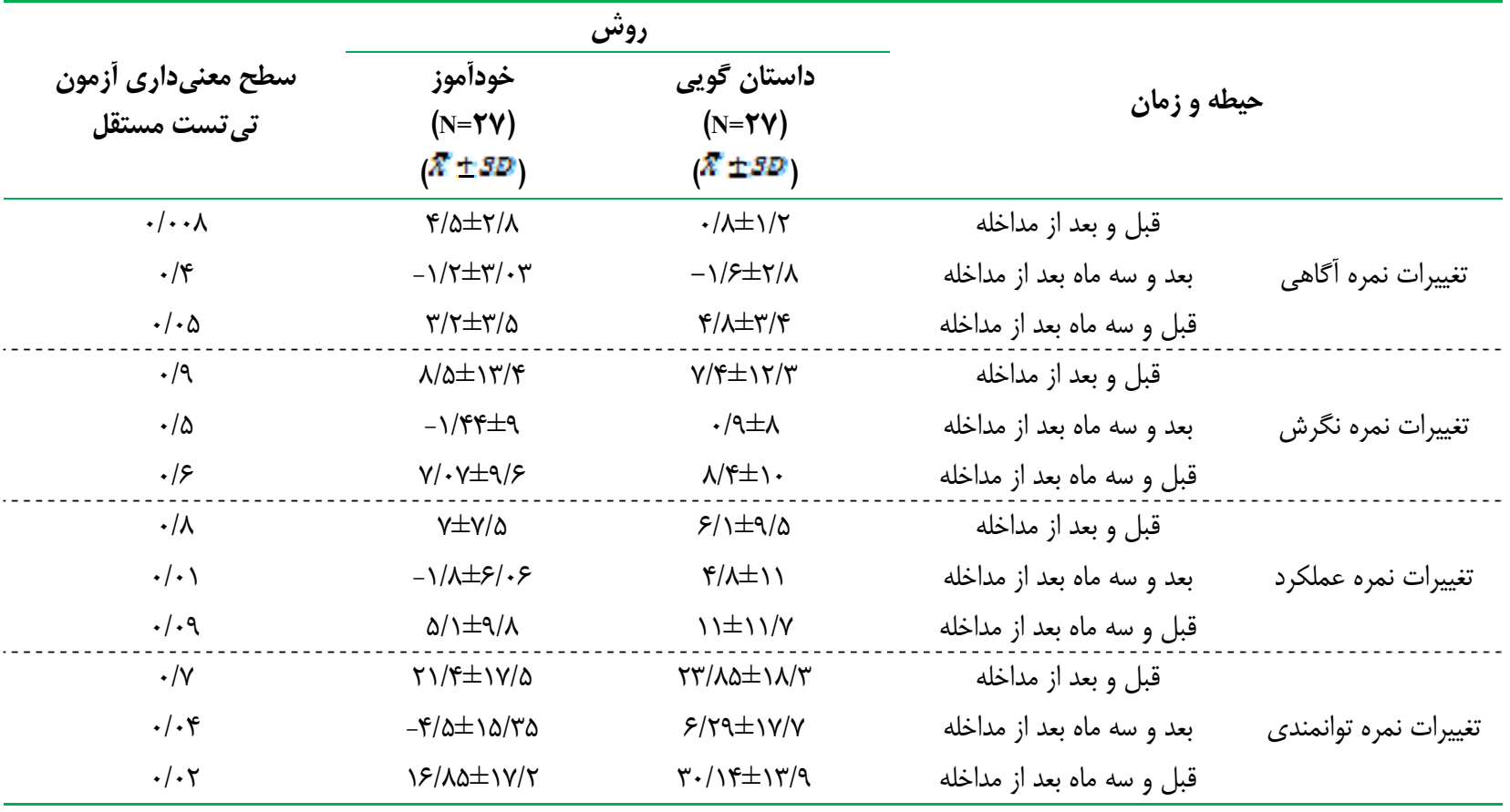

در مراقبت از كودى روشن مىسازد تا آنجا كه در مطالعات

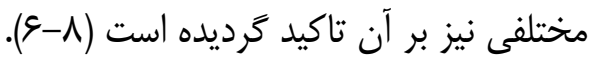

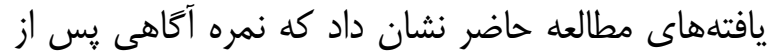

مداخله نسبت به قبل از آن، در هر دو روش بلهور معنىدارى لئل

كودكان در سنين كودكى با توجه به محدوديتهاى فيزيولوزيكى، رفتارى و تكاملى خود، به مراقبتِ يك عامل

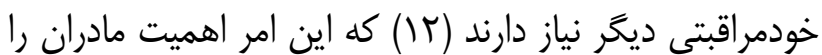


خوشبينى شده و كاربرد اين روش منجر به پايدارى نسبى

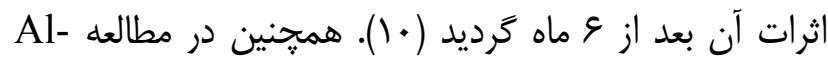
Mansour موفقيت گروه هدف در درك و خواندن زبان انخَليسى داشت باني

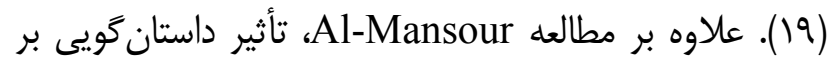

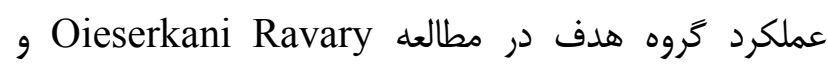

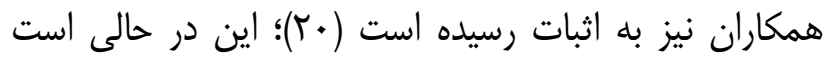

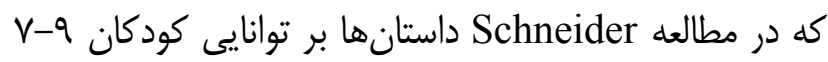
سال در استفاده از عبارات اشاره، معرفى شخصيتها و و اشيتاء تأثيرى نداشتند (rال در).

قصدَّيى يكى از روشهاى آموزشى است كه مىتواند

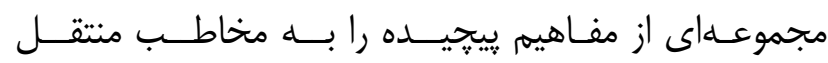

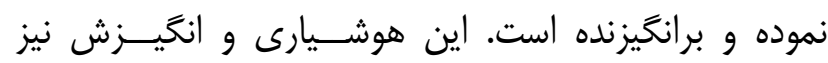

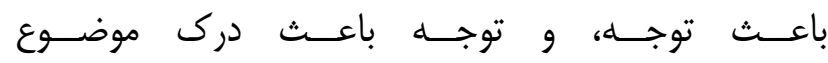
مــىشــود كه خود باعث مىشود تا در قصلكويى، شنونده تا

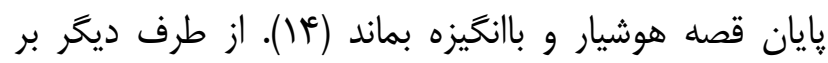

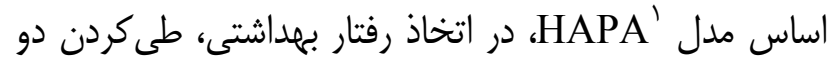

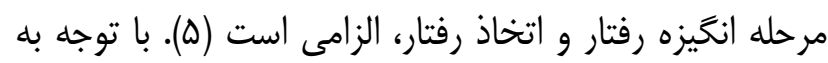

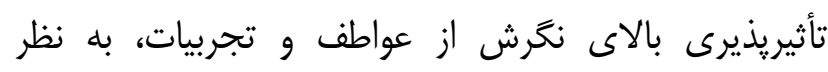

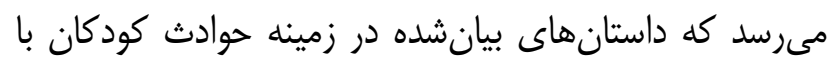

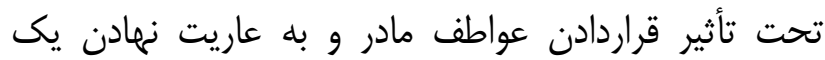

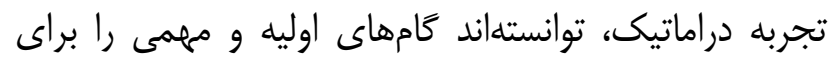

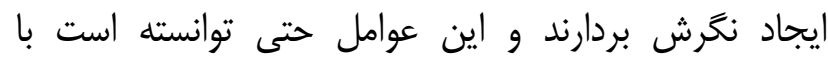

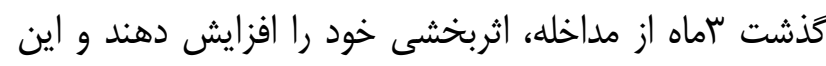

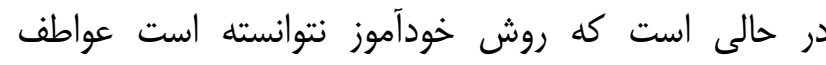

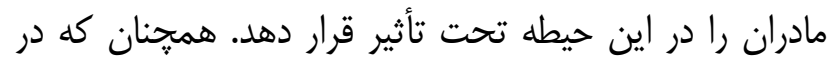

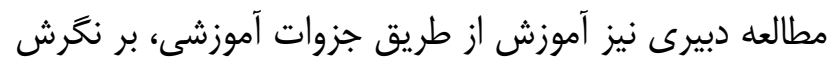

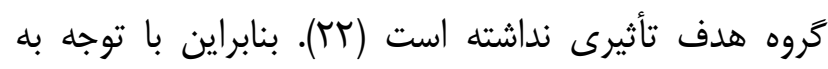

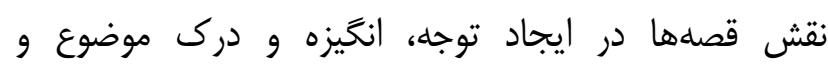

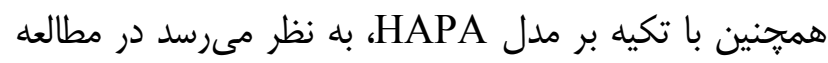

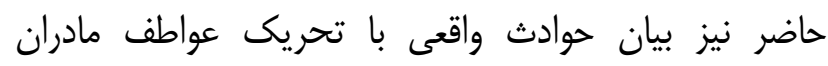
توانسته است باعث ايجاد انكيزه شود كه اين انخيزش نيز بئ تحرئ
افزايش داشته است؛ هر קند كه هيجيك از اين دو روش

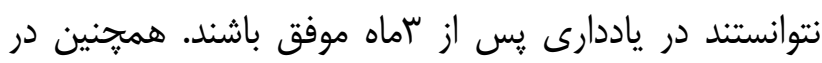

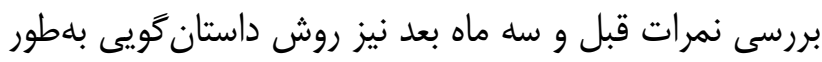

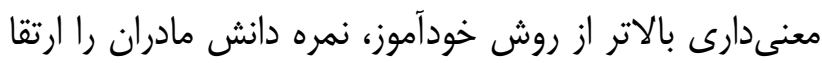

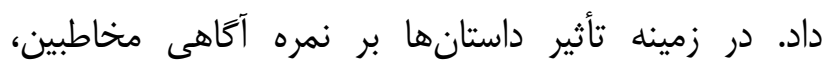
Falavigna

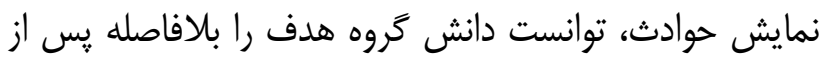

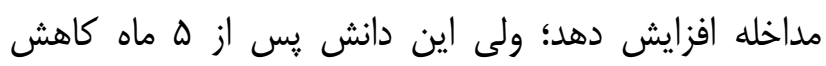

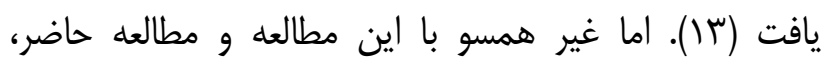
Christiansen

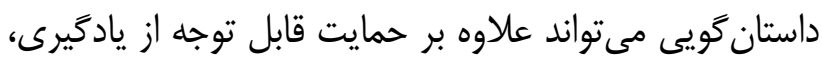

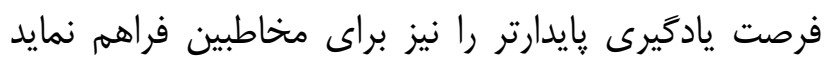

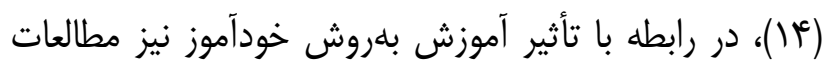
بسيارى، به اثربخشى جزوات و كتابجههاى آموزشى بر سطح

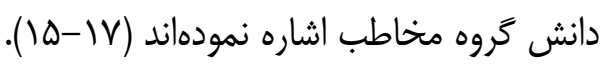

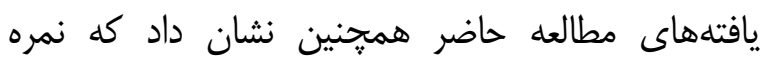

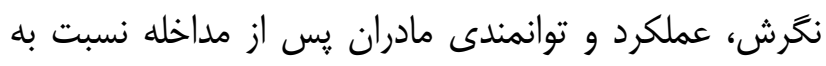

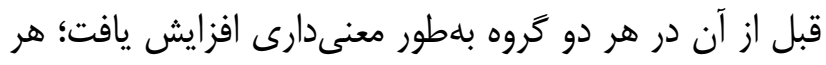

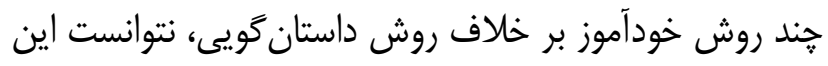

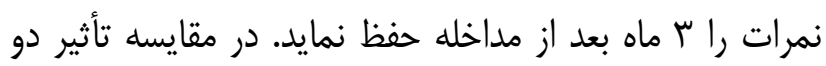

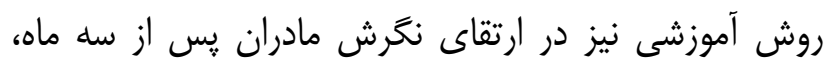

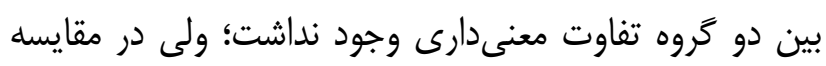

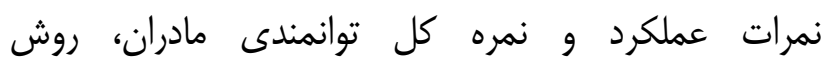

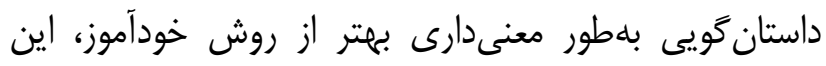
نمرات را ارتقا بخشيد. در مطالعه Morrongiello نيز مداخله آموزشى در زمينه حوادث واقعى كودكان، منجر به افزايش

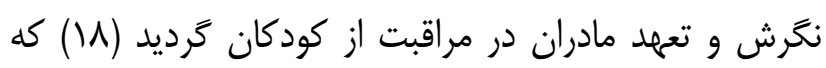

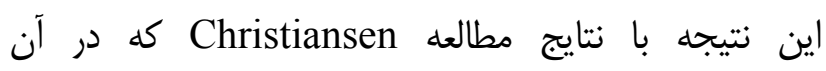

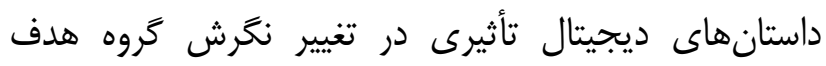

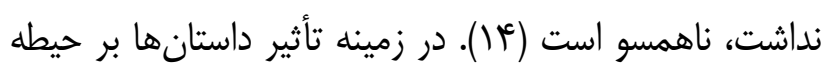

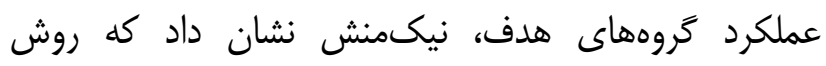

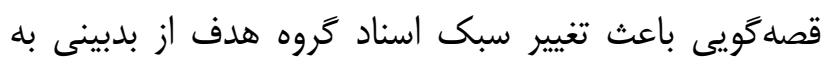


اتخاذ رفتار صحيح بهداشتى را در بي داشته است. اين در نتيجه كيرى

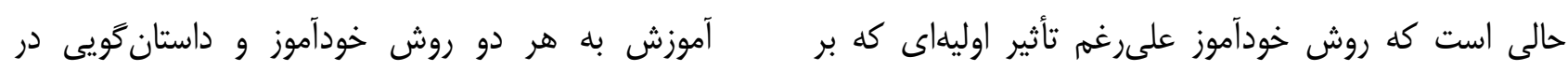

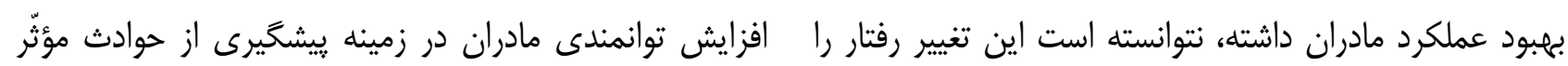

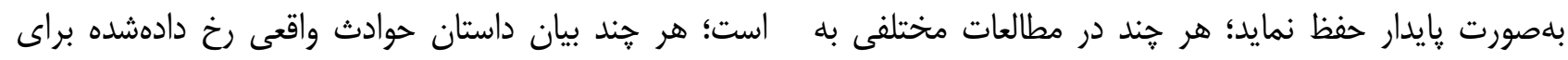

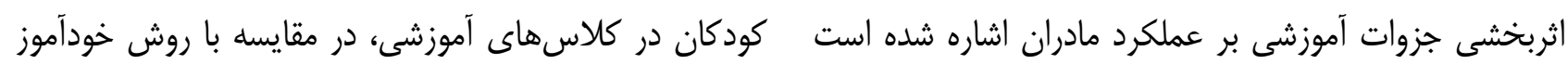

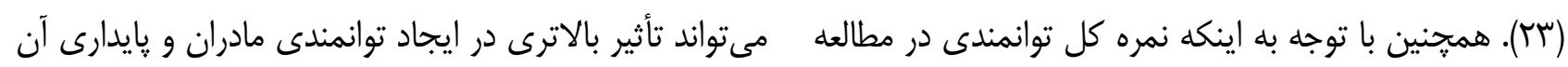

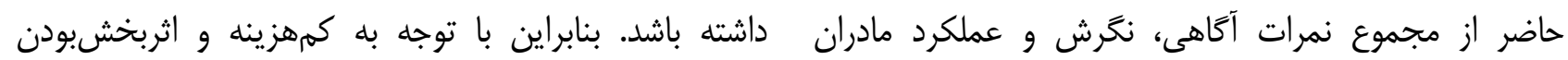

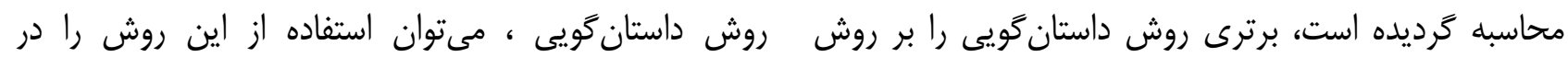

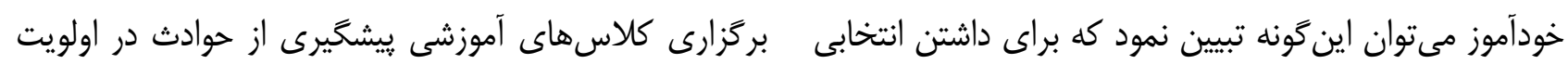

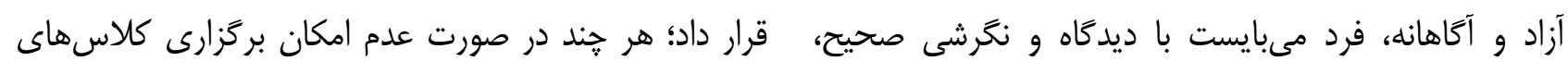

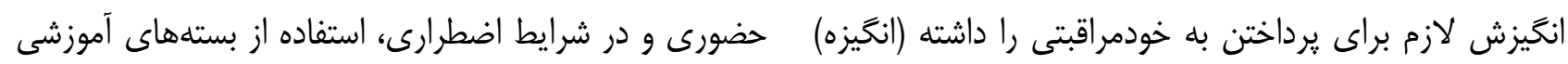

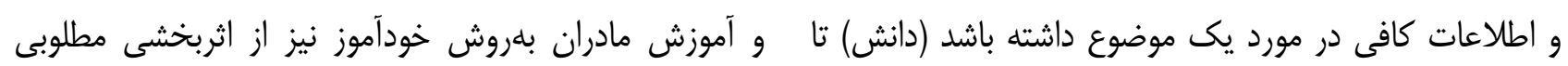

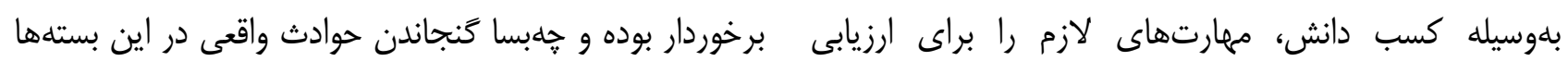

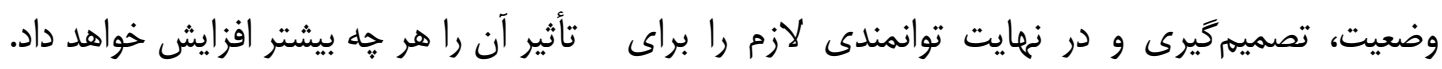

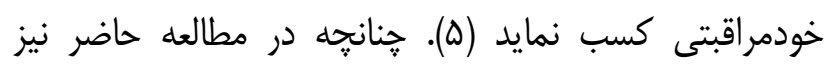

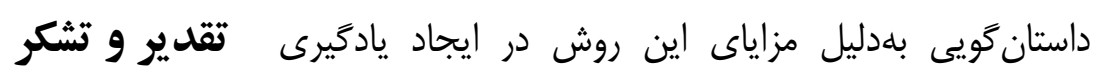
بدينوسيله از حاميان اجراى پايان نامه، دانشكده يرستارى و مامايى بيرجند و معاونت تحقيقات و فناورى دانشگاه علوم إنان

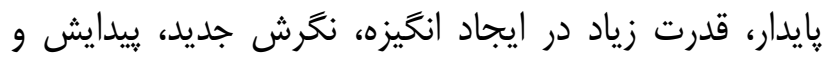
يزشكى بيرجند تشكر و قدردانى مى

\section{تضاد منافع}

نويسندكان مقاله اعلام مى دارند كه هيج گَونه تضاد

$$
\text { منافعى در يزوهش حاضر وجود ندارد. }
$$

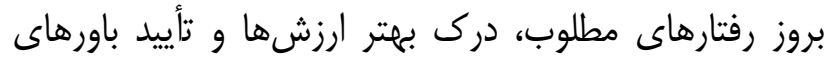

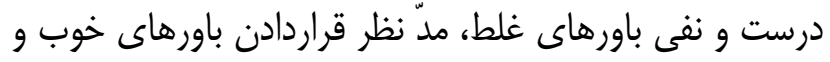

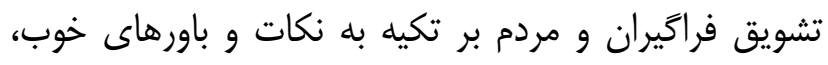

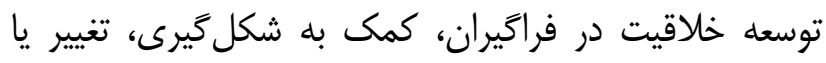

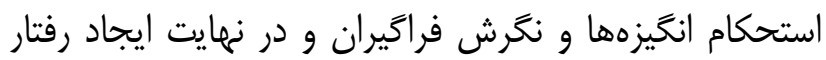

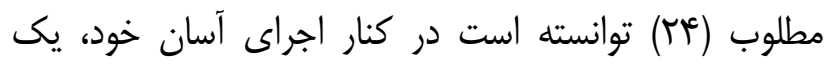
روش اثربخش در آموزش مخاطبين باشد.

1- Rafati M, Ghotbi M, Ahmadnya H. Principles of Disease Prevention and Care. $1^{\text {st }}$ ed. Tehran: Book Garden; 2008. [Persian]

2- Tabibi Z. Incidence, Causes and Prevention of Child Accidents in Iran: an Analysis of Existing Studies. Journal of Family Research. 2009; 5(18): 179-205. [Persian]

3- Mobasheri F, Azizi A, Rastbaf F. The Epidemiological Pattern of Injuries among Children under 15 Years of Age in Fasa in 2013. J Fasa Univ Med Sci. 2016; 6(1): 69-78. [Persian]

4- World Health Organization. 10 facts on injuries to children. 2012; Available at: http://www.who.int/features/factfiles/injuries_children/en. Accessed January 6, 2019.

5- Rafiefar SH, Attarzada M, Ahmadzadeasl M, Dezhpasand S, Tehrani Banihashmi SA, Mohamadi A, et al. Systematic empowerment of people to take care of themselves. $1^{\text {st }}$ ed. Tehran: Mehrravesh publishing; 2005. [Persian] 
6- Al Mutairi M, Al Harthy N, Al Qahtani A, Al Fahmis, Al Zidi B, Jaffer RE. Home Injury prevention in children: Attitudex \& Awarness of the caregivers at king Abdul-Aziz 2 Medical city- Pediatric Emergency, Riadh, KSA. Br J Med Med Res. 2016; 18(11): 1-10. DOI: 10.9734/BJMMR/2016/29832

7- Gaines J, Schwebel DC. Recognition of home injury risks by novice parents of toddlers. Accid Anal Prev. 2009; 41(5): 1070-4. doi: 10.1016/j.aap.2009.06.010.

8- Shahraki A, Mardani M, Arab M, Firoozkoohi Z. Infant under 1-59 month mortality causes in Zabol. Iran J Nurs Res. 2010; 5(17): 6-13. [Persian]

9- Brahmandpor F, Ardestani M. Manual selection of media and methods of health education. $1^{\text {st }}$ ed. Tehran: Arman Brasta Publishing; 2013. [Persian]

10- Nikmanesh Z, Kazemi Y. An examination of the effects of a Model for Teaching of Optimism by Storytelling on Attribution Styles of children. Research in Psychological Health. 2008; 2(3): 5-13. [Persian]

11- Sajadi Hazaveyee M, Shamsi M. Knowledge, attitude and practice of mothers trying to prevent febrile convulsion in children in Arak. J Urmia Nurs Midwifery Fac. 2011; 9(2): 76-83. [Persian]

12- Memarian R. Application of nursing concepts and theories. $2^{\text {nd }}$ ed. Tehran: Tarbiat Modares Universit; 2012.

13- Falavigna A1, Teles AR, Velho MC, Medeiros GS, Canabarro CT, de Braga GL, et al. Impact of an injury prevention program on teenagers' knowledge and attitudes: results of the Pense Bem-Caxias do Sul Project. J Neurosurg Pediatr. 2012; 9(5): 562-8. doi: 10.3171/2011.12.PEDS11169.

14- Christiansen A. Storytelling and professional learning: a phenomenographic study of students'experience of patient digital stories in nurse education. Nurse Educ Today. 2011; 31(3): 289-93. doi: 10.1016/j.nedt.2010.10.006.

15- David A, Banerjee S. Effectiveness of "palliative care information booklet" in enhancing nurses' knowledge. Indian J Palliat Care. 2010; 16(3): 164-7. doi: 10.4103/0973-1075.73647.

16- Shureshi P, Ahmadi Chenari H, Ahmadi M, Jesmi AA. Effect of Education by Lecture and Pamphlet Methods on Soldiers Knowledge about Meningitis Disease. J Mil Med. 2015; 17(3): 181-6. [Persian]

17- Mohamadirizi S, Bahadoran P, Fahami F. Comparsion between the impacts of e-learning and booklet education on primigravida women's satisfaction about postpartum care. Iran J Obstet Gynecol Infertil. 2013; 16(61): 1-8. [Persian]

18- Morrongiello BA, Zdzieborski D, Sandomierski M, Lasenby-Lessard J. Video messaging: What works to persuade mothers to supervise young children more closely in order to reduce injury risk? Soc Sci Med. 2009; 68(6): 1030-7. doi: 10.1016/j.socscimed.2008.12.019

19- Al-Mansour NS, Al-Shorman RA. The effect of teacher's storytelling aloud on thereadingcomprehension of Saudi elementary stage students. Journal of King Saud University - Languages and Translation. 2011; 23(2): 69-76. doi: 10.1016/j.jksult.2011.04.001

20- Toieserkani Ravary M, Unesi SJ, Usefi Looye M. The Effectiveness of a Story-Based Program on the Social Competence of Disordered Children. Journal of Family Research. 2008; 4(1): 63-76. [Persian]

21- Schneider P, Hayward D. Who Does What to Whom: Introduction of Referents in Children's Storytelling From Pictures. Lang Speech Hear Serv Sch. 2010; 41(4): 459-73. doi: 10.1044/0161-1461(2010/09-0040)

22- Dabiri F, Abedini S, Shahi A, Kamjoo A. The effect of different methods of health education on knowledge, attitudes and practice of female students regarding menstrual hygiene in Bandar Abbas (2006). Med J Hormozgan. 2009; 12(4): 271-9. [Persian]

23- Golshiri P, Sharifirad G, Baghernezhad F. Comparison of two methods of education (lecture and self learning) on knowledge and practice of mothers with under 3 year old children about growth monitoring and nutritional development stages. Iran J Med Educ. 2011; 10(5): 927-36. [Persian]

24- Mostafazadeh F. Storytelling: a New Clinical Education Method. Research in Medical Education. 2010; 2(2): 53-8. [Persian] 